\title{
The Social Policies Presidents Make: PRE-EMPTIVE LEADERSHIP UNDER NIXON AND CLINTON
}

\author{
Daniel Béland and Alex Waddan \\ (Final draft published in Political Studies, 54(1): 65-83 \\ [Blackwell/Political Studies Association]; PDF copy of the published \\ article available upon request: dbeland@ucalgary.ca)
}

\begin{abstract}
Grounded in Stephen Skowronek's typology of presidential leadership, this article furthers our understanding of 'pre-emptive leadership' through a comparative analysis of the welfare and Social Security reforms pursued by presidents Richard Nixon and William Clinton. Although not identical, their experience in these areas provides a valuable insight into the difficulty of wielding power in an inhospitable political environment. The article starts with a brief presentation of Skowronek's typology before discussing the electoral strategies employed by both presidents as they attempted to frame political identities that would allow them to compete successfully in unfavourable ideological and political circumstances. The article then specifically focuses on the politics of welfare and Social Security reform as the two presidents used these issues as part of their effort to craft distinctive political images and attract wider electoral support. This comparative analysis reinforces the concept of 'preemption' as a valuable tool in understanding presidential behaviour. It also underlines, however, the limits of pre-emptive leadership. Pre-emptive strategies can be effective at election time, but they are less likely to succeed in the legislative arena. This reality complicates the presidential search for genuine policy legacies.
\end{abstract}

The presidencies of Richard Nixon and Bill Clinton both witnessed dramatic constitutional confrontations arising from the personal failings of the two men. In both instances, however, the unravelling of their presidencies reflected not just individual frailties but also that both were confronted with a vehement hostility from many in the political class who simply never reconciled themselves to the legitimacy of their presidencies. To their opponents these were presidents who had somehow usurped the established partisan and ideological order. Put another way, they were elected on the back of short-term public disapproval of the previous regime that reversed the underlying ideological and political currents. This is difficult to quantify, but an insightful approach is to examine their efforts through the lens of the presidential 
typology developed by Stephen Skowronek (1993). His model places the presidential capacity to act in a constraining institutional and ideological context rooted in specific historical legacies; and for Nixon and Clinton that context presented complex challenges. Popular disaffection had helped them to get elected, but it was not clear how they were going to be able to harness this mood and guide it in a more positive direction. In Skowronek's scheme this places Nixon and Clinton as 'pre-emptive' leaders needing to navigate a course in the face of adverse ideological currents.

This article provides empirical investigation of this idea of 'pre-emptive leadership' through a comparative analysis of the welfare and Social Security reforms pursued by Nixon and Clinton. Although not identical, their experience in these areas provides a valuable insight into the difficulty of wielding power in an inhospitable political atmosphere. It is not that electoral or legislative success simply eludes preemptive leaders as both Nixon and Clinton won re-election and signed substantive bills into law in one or other of the areas under discussion. Their experiences do illustrate, however, the particular difficulties pre-emptive leaders have in keeping control of the agenda, even on issues they themselves have pushed to the forefront of it.

\section{PRESIDENTIAL LEADERSHIP AND PRE-EMPTIVE POLITICS}

Adopting an historical institutionalist perspective, Skowronek reflects that while all presidents arrive at the White House determined to pursue their own leadership projects their "political authority turns on [their] identity vis-à-vis the established regime' (1993, p. 34). In the most basic terms they come to office either in 'opposition to the pre-established regime, or ... affiliated with its basic commitments' (p. 35). Whether opposition or affiliation to the regime enhances or diminishes 
political authority, however, depends on the status of the existing arrangements. Is the regime in resilient working order or are its ideology and political hegemony waning? From here Skowronek identified 'four structures of presidential authority' with the leadership potential of White House incumbents fluctuating according to their place in this model.

Those Presidents most often regarded as 'heroic', that is, who most dramatically change the political landscape, are opposition leaders elected at a time when the existing regime has run its course. These are presidents elected in times of turmoil with a mandate to reform, allowing them to operate in a fashion relatively unconstrained by the institutional inertia built into the U.S. political system. The obvious example of a modern era 'reconstructive' president is Franklin Roosevelt. A more recent example is Ronald Reagan. This is a more problematic case as the problems the U.S. faced at the end of the 1970s, while manifest and significant, did not match the breakdown experienced during the Depression. Moreover, while Reagan's triumph over an incumbent President was accompanied by the Republican capture of Senate, the House remained in Democrat hands leaving that party a critical legislative veto point. Yet, as Skowronek points out, Reagan emphatically cast himself in the role of a reconstructive President (1993, pp. 409-29) and central to his leadership project was a repudiation of the New Deal regime, or at least its Great Society manifestation (Anderson, 1988).

If reconstructive presidents lie at one end of the spectrum the presidents of 'disjunction' lie at the other. These are presidents affiliated to the existing regime but at a time when that regime is coming to the end of its political life. Skowronek's emphasis is on recurrent patterns rather than defined political cycles so his model does 
not predict when a regime will fall into decline, ${ }^{1}$ but clearly the economic uncertainties of the Depression and at the end of the 1970s undermined the authority of Presidents Hoover and Carter and the political legitimacy of the regimes they represented. It is the perceived failures of these presidents that in turn open the door for presidents of reconstruction to attempt to fill the political vacuum and establish a new order.

A third type of leadership in Skowronek's model, where affiliated presidents build on the work of a reconstructive predecessor, is 'articulation'. Here presidents are faithful to the dominant political and ideological creed of their time. Skowronek notes that 'More presidents fit this description than any other' (1993, p. 41), but this should not suggest simply some sort of 'politics as usual'. Depending on the institutional and partisan context presidents of articulation may be in a position to rush ahead or they may be severely circumscribed in their capacity to enhance the political project they inherited. The experiences of Presidents Lyndon Johnson and George H. Bush suggest that both scenarios can be politically treacherous. Johnson chose to retire from political battle and Bush slumped dismally through the 1992 campaign. Their successors, however, Presidents Nixon and Clinton, while both presidents of partisan opposition were not elected in order to repudiate the existing regime. Their position is well described by Skowronek's final category: pre-emptive leadership.

Here presidents find themselves, 'Intruding into an ongoing polity as an alien force, they interrupt a still vital political discourse' (Skowronek, 1993, p. 43). These

\footnotetext{
1 In a discussion in 1995 Peri Arnold criticised Skowronek for being overly deterministic (1995, pp. 497-9). Skowronek responded that his model is not about a pre-determined cycle but that presidents choose to behave in ways that produce recurrent patterns (1995).
} 
are presidents who win office despite their partisan affiliation rather than because of it. From the start, therefore, they are compromised in their capacity to shape the political world. They are different from presidents of 'disjunction' inasmuch as they are aware of their peculiar circumstances and try to reconcile the contradictory pressures. The difficulty comes in developing a viable political strategy that accommodates the continuing, unsympathetic, ideological framework and yet simultaneously allows them to create a new and sustainable political coalition that works at both elite and popular levels. Skowronek notes that such presidents are operating in the most peculiar of circumstances-potentially isolated both ideologically and institutionally.

Skowronek also acknowledges that pre-emptive presidencies are the most difficult to analyse, and it is noteworthy that in the 1993 edition of his book he conducts twelve presidential case studies, but none are of pre-emptive presidents. $^{2}$ In a discussion of this edition Sydney Milkis comments on how the concept of preemption does identify 'presidents who fight against the role history has marked out for them' but he adds that Skowronek says relatively little about these presidents; 'they are mentioned but not discussed' (1995, p. 488). An understanding of the possibilities and limits to pre-emptive presidential leadership, however, seems just as vital as the other categories discussed. It is important to note that this is not simply a case of measuring success through legislative score keeping. Indeed all presidents, even those supported by partisan majorities in Congress, face formidable institutional obstacles that

${ }^{2}$ Skowronek does, however, explicitly describe Nixon as a pre-emptive President (1993, p.44). Furthermore, the 1997 edition has a chapter framing Clinton in preemptive terms (1997). 
frustrate their leadership capacity. To contemporaries, Franklin Roosevelt's administration was subject to institutional and political restraints that prevented legislative action in substantive areas but, in hindsight, few could dispute the significance of the New Deal's political and policy legacy. The question for preemptive leaders is to what extent they can bridge the gap between winning elections and building a substantive policy legacy that in turn restructures political allegiances.

\section{Getting Elected}

To say that Nixon and Clinton were somehow elected out of sequence really means that they won the White House by, respectively, interrupting periods of Democrat and Republican hegemony in presidential elections before it was clear that these periods of party ascendancy were under threat. Clearly, in 1968 and 1992, the U.S. was not enjoying 'peace and prosperity' which helped the two to buck the dominant electoral trend; but neither year stands out as heralding a 'reconstructive' era where the new president was expected fundamentally to rollback the terms of the existing political and socio-economic settlement.

Indeed, one striking similarity between Nixon and Clinton is that both won the White House with only limited personal mandates. The most notable shifts in voting patterns from 1964 and 1988 to 1968 and 1992, respectively, were the collapse of the vote for the main opposition candidate and the presence of maverick third party challengers. In 1968, Nixon won just 43.4 percent of the popular vote with George Wallace taking 13.5 percent. Nixon also became the first President since the 1850 s to be elected with his party controlling neither chamber of Congress. Clinton did start his term with Democrats in control of Congress; still, he had won only 43 percent of the vote, as Ross Perot, a man with no previous political experience, took 19 percent of 
votes cast. Thus, while the 1968 and 1992 elections illustrated significant disaffection with the established regimes, they hardly constituted strong, positive endorsements of the new Presidents. This was reflected in the size of the vote for Wallace and Perot who, albeit in different ways, were quintessential 'outsider' candidates.

These voting patterns presented a complex analysis for new presidents anxious about their future political prosperity. As it was, Nixon overwhelmingly won a second term and Clinton did so comfortably suggesting that both had gained wider support. In hindsight, however, it is apparent that neither created lasting coalitions at an elite or popular level that restructured the political landscape. Gerald Ford and Al Gore did lose by the narrowest of margins in 1976 and 2000, respectively, and both may well have won if they had not been dogged by their predecessors' scandals. Yet, even if either of these electoral near misses had turned out to be hits neither Ford nor Gore would have come to office with a strong ideological and partisan inheritance in contrast to presidents of articulation such as Harry Truman and George H. Bush.

\section{Establishing A Political Identity}

It is the struggle to create a governing philosophy that brings us back to the confines of pre-emptive leadership. Pre-emptive candidates have the opportunity to upset the ascendant ideological and partisan trend and win the presidency because of the onset of disruptive contingent events. The electoral imperative for such candidates is to develop strategies allowing them to exploit the discomfort of the incumbent ideology without reminding the voters of why that has been their long-term preferred ideology. Thus pre-emptive candidates have a complex task. They will want to project their own party's traditional strengths while disassociating themselves from those images that had contributed to the party's sequence of political failures. Furthermore, 
in order to establish the future grounds for their own political project they may proclaim new and dynamic solutions to pressing problems that will surpass the previous regime's efforts. As presidents, the problem comes in implementing substantive enough policies to lay claim to a new politics that has a resilient and governing quality rather than the transience of campaign rhetoric.

The first step, though, is to get elected, and in this context it is worth reversing the historical order and looking first at Clinton whose effort to establish a national political identity in 1992 was a classic statement of pre-emptive politics (Béland et al, 2002). Clinton's political ascent reflected the growing influence of the so-called New Democrats and their organized activity through the Democratic Leadership Council (DLC) (Hale, 1995; Baer, 2000). The DLC, established following Mondale's crushing defeat in 1984, rallied against 'liberal fundamentalism' within the Democratic Party (Galston and Kamarck, 1989) and insisted that the changing socio-economic environment demanded a bold policy synthesis that ignored the traditional confines of 'liberal' and 'conservative' (Marshall and Schram, 1993). As a former chairman of the DLC, Clinton's campaign rhetoric echoed New Democrat themes as it attacked Republicans for their anti-government rhetoric while asserting that the Democrats were no longer the party of Big Government (Clinton, 1992). One manifestation of this strategy was to present the 'third way' as a new road map.

Nixon was not quite in such a position in 1968. Unlike Clinton, he already had a national profile when running for President and so was not at a point to assert that he was offering a new choice on the political scene. Neither did he declare an intention to reinvent the Republican Party. His task was to negotiate a path that had sufficient resonance to appeal to the 'silent majority' without suggesting a repeat of what might be termed Goldwater's 'conservative fundamentalism.' Nixon was helped in 
establishing his centrist position by the fact that his two main challengers for the GOP nomination, Nelson Rockefeller and Ronald Reagan, were seen as being from the liberal and conservative wings of the party, respectively, which made him 'the only candidate acceptable to all factions of the party' (Small, 1999, p. 23). Kotlowski notes that Nixon pursued a strategy of 'moderation' in order 'to unify the GOP' as it was clear that the "party would never gain majority status if either its liberal or conservative wing was "sliced off"” (2001, p. 3).

One problem with understanding the political implications of Nixon's 1968 triumph is the potentially distorting lens of hindsight. The 1968 election clearly heralded a period of Republican domination of the White House leading some to see this as a period of Republican realignment; however, Nixon should not be seen as the harbinger of the reconstructive New Right. Nixon was aware of the potential for upsetting the New Deal regime and was guided by Kevin Phillips' book The Emerging Republican Majority (1969), but in the late 1960s this did not entail embracing plans to dismantle the U.S. welfare state. Nixonism rebuked the Great Society for overstepping the mark but did not repudiate the New Deal's policy legacy. Overall, the Nixon era saw a continuation of Great Society levels of domestic spending (Mayhew, 1991, pp. 81-9). As a candidate Nixon was able to exploit unhappiness over the continuing war in Vietnam and disquiet over urban riots and rising crime but in the late 1960s 'public support for an activist government was still strong' (Berman, 1994, p. 9). The point here is not to present a revisionist account of the Nixon presidency, but to note that, like Clinton, he came to office when there was serious dissatisfaction with the previous regime though not (yet) a clear (conservative) 
picture of where to go next. ${ }^{3}$

It is important, of course, not to overstate the similarities between Nixon and Clinton and the politics they encountered. In terms of a self-conscious 'fit' with Skowronek's model, the case to label Clinton pre-emptive is more compelling; but Nixon too had to counter the problems of his party's past both in terms of the immediate case of 1964-when arch-conservative GOP candidate Barry Goldwater experienced electoral humiliation-and the longer term dilemma of countering the dominance of the New Deal coalition.

\section{Social Policy as Pre-emptive Politics}

In order to navigate the pre-emptive context, both administrations went back to the centrepiece of New Deal legislation, the Social Security Act, and targeted two of the programs created in 1935. They saw successful reform of welfare and Social Security-two high profile but very different income maintenance programs-as a mean of simultaneously extending their electoral appeal beyond their party's traditional base while establishing a substantive policy legacy. Thus Nixon moved away from the default conservative position while Clinton attempted to rebut his party's liberal image. In the process, the two expended considerable political energy pursuing legislation that upset some core constituencies with the hope that this would substantiate their political character and in turn create a new political space.

The proposals they set forth in order to achieve this were quite distinct, but there was a peculiar symmetry in the final legislative endgames. Nixon presided over significant amendments to Social Security while Clinton signed the Personal

\footnotetext{
${ }^{3}$ See Greenberg, 2003, pp. 304-337, for a review of the revisionist literature painting Nixon as a liberal.
} 
Responsibility and Work Opportunity Reconciliation Act (PRWORA) that constituted a major revision of welfare. While both claimed success, they had, in reality, effectively been stampeded by a Congress controlled by the partisan opposition into consenting to legislation that went further than they had originally intended. On the other hand, Nixon's proposed welfare reform and Clinton's flirtation with Social Security reform produced no end product with the two finally scuttling back to their party's more traditional stances on these matters.

One should not treat the four reform efforts as co-equal case studies because different levels of political capital were spent on each (in particular Nixon's efforts at welfare reform were more enduring than Clinton's dalliance with Social Security reform), but they illuminate well the complexities of operating in a pre-emptive environment. In particular, they illustrate the difficulties in negotiating the interface between politics and policy when attempting to extend a political coalition beyond its core base through innovative policy design.

\section{Welfare Reform}

What to do about the Aid to Families with Dependent Children program—a means-tested cash benefit predominantly supporting poor single parent families-was a consistently divisive theme in U.S. politics from the mid-1960s until the passage of PRWORA. Some reasons for this were objectively quantifiable, with others less so. There was significant growth in the welfare rolls, particularly in the time around Nixon's and Clinton's initial triumphs. In 1960 the average monthly number of families receiving AFDC was 803,000, but this jumped to just over 1.9 million by 1970. There was as a further spurt between 1990 and 1994 when the figure increased from under 4 to just over 5 million families (US, 1998, p. 402). 
This data, however, tells only a part of the story because welfare was already an issue ripe for political manipulation. After studying opinion poll data, Weaver et al commented, “Welfare”" (...) is perceived as being at odds with the widely shared American values of individualism and work ethic' (1995, p. 607). Furthermore, the emotive question of race further complicated discussions of welfare. ${ }^{4}$ Indeed, according to Gilens 'the symbolic power of welfare as a political issue stems in large measure from its racial undertones' (1996, p. 602). What is clear is that the racial aspect to welfare issues amplified the debate about whether AFDC undermined work ethics, family values and social order making welfare reform a potential political and policy tinderbox. Furthermore, the 'perversity thesis' associated with Charles Murray's Losing Ground exploited the negative image of 'big government' to turn the population against welfare. Depicting welfare as a source of negative unintended consequences, Murray and other conservative intellectuals thus undermined the legitimacy of AFDC (Murray, 1984; Mead, 1992).

If anything, though, this hazardous nature enhanced welfare's attraction to Nixon and Clinton as an issue where they could project their own distinctive politics. When analysing how, and how successfully, they did this, however, it is important to underline specific rhetorics and realities. For candidate Clinton, the campaign mantra of 'ending welfare as we know it' was a deliberate and very public part of his preemptive, New Democrat, strategy to refute the image of soft-hearted Democrats. Welfare reform also figured conspicuously in Nixon's campaign, but his promise to 'clear up the welfare mess' was a traditional Republican message. His act of pre-

\footnotetext{
${ }^{4}$ Minorities did constitute a disproportionate percentage of those on the rolls but not a majority: in 1993, 39 percent of AFDC female family heads were African-American (US 1998b, p.391)
} 
emption came in the details of his reform plan that was unexpectedly liberal. In fact, the perilous task both faced in managing the welfare issue to their own advantage is illustrated by the manner in which their legislative efforts belied their campaign rhetoric. Thus, while both Nixon and Clinton exploited the welfare issue quite crudely as a rhetorical campaigning tool, they then put forward quite complex proposals once in office. Indeed, Nixon's Family Assistance Plan (FAP) and Clinton's Work and Responsibility Act (WRA) both combined elements of liberal and conservative thought in innovative ways.

Few took Nixon's complaints about the dangers of dependency to mean that he would promote a guaranteed minimum income for U.S. families with children; yet this is exactly what FAP did. Introduced in 1969, FAP offered to guarantee an income of $\$ 1,600$ to a family of four with the qualification that the head of household make a work effort. While $\$ 1,600$ was well below the poverty line of $\$ 3,721$ for a family of four (US, 1971, p. 321), it would have created a federal minimum that would have chipped away at the low-wage basis of the southern political economy in particular. Furthermore, families would have been eligible to continue receiving benefits, as they earned, on a sliding scale up to a total household income of $\$ 3,920$. FAP would also have integrated all poor families into a single income program unlike AFDC, which targeted mostly non-working, poor, single parent families. Nixon did emphasize the work requirement in public, but the reality appears to be that it was never intended as a serious qualification (Bowler, 1974; Burke and Burke, 1974; Mead, 1986). It stipulated that recipients had to register for work, but they would only be sanctioned if they explicitly turned down a job and would only lose $\$ 300$ of benefits as a consequence. According to Pat Moynihan, a key architect of FAP, Nixon confided, 'I 
don't give a damn about the work requirement (...). This is the price of getting the \$1,600’ (1973, pp. 219-20).

What is so intriguing about FAP is that it pre-empted not popular opinion, which showed at best ambivalence about the idea of a guaranteed income (Erskine, 1975), but rather a section of elite opinion. Through the 1960s, a series of respected economists and government-commissioned reports proposed tackling poverty through explicit income guarantees. The gathering of advocates reflects the idea's hybrid ideological roots, but by the late 1960s it was liberal economists such as James Tobin (1968) who were the strongest supporters. In the summer of 1968, a petition signed by 1,000 economists gave public voice to the idea (Small, 1999, p. 187). Furthermore, in 1968 the Kerner Commission (US, 1968), established to investigate the causes of the urban riots of the mid-1960s, and in 1969 the President's Commission on Income Maintenance Programs (US, 1969) both concluded government should guarantee an annual income to poor families. The Supreme Court contributed to the reformist mood by easing AFDC eligibility rules (Teles, 1996, pp. 107-17). As Mead notes, 'The policy making behind the proposals showed the consensual patterns characteristic of the Great Society. Guaranteed income drew surprising support from business as well as social workers and welfare advocacy groups' (Mead, 1986, p. 97).

As it was, FAP met with a mixed reception. It passed in the House but was killed off in the Senate Finance Committee (SFC) by a coalition including liberals such as Eugene McCarthy and Fred Harris and the arch-conservative John Williams. This reaction illustrates the difficulty of pre-emptive leadership. Some, traditionally in the liberal camp, acknowledged Nixon's innovation. For example, a New York Times editorial reflected on the 'excellent' framework for reform that constituted a 'bold attempt to transform an apparatus thrown together thirty-five years ago' (New York 
Times, 1969). More generally, however, partisanship and anti-Nixon sentiment characterized the liberal response. Thus Senators Hubert Humphrey and George McGovern ridiculed the plan while McCarthy, with the National Welfare Rights Organization, organized two days of 'people's hearings' at which FAP was consistently denounced before a decisive SFC vote.

FAP's other problem was that it did alienate many conservatives. Prominent critics included the Chamber of Commerce, the American Conservative Union and California's Governor, Ronald Reagan, who worried that the plan would undermine work ethics and traditional family values. Congressman Phillip Landrum fretted about how much he would have to pay to get his shirts ironed (Quadagno, 1994, p. 130). In the end Nixon gave up and the GOP returned to a more traditional stance in its 1972 party platform declaring, 'We flatly oppose programs ...which embrace the principle of a government-guaranteed income., 5

Nixon's own reflections on FAP provide a revealing insight into the difficulties of pre-emptive leadership. Nixon wanted welfare reform to constitute ‘creative and innovative social legislation' (Nixon, 1978, p. 425). Describing FAP as 'an idea ahead of its time' Nixon expected opposition from conservatives but anticipated 'a legislative alliance with Democrats and liberals' (p. 427). Hence the liberal opposition surprised him, leading to the comment: 'As Moynihan observed, it was as if they could not tolerate the notion that a conservative Republican President had done what his liberal predecessors had not been bold enough to do' (p. 427).

More than twenty years later, President Clinton's WRA produced similar reactions when it won praise from newspaper editorials but drew fire from both the

\footnotetext{
${ }^{5}$ Cited in Congressional Quarterly Weekly Report, August 16, 1972: 2160.
} 
left and right. ${ }^{6}$ Given the passage of PRWORA in August 1996, the earlier WRA, put forward in the summer of 1994, has been sidelined as something of a historical footnote, but Clinton's attempt to reconcile demands for a more coercive workfare approach with continuing government support for the most vulnerable deserves some scrutiny. The headline proposal was that unconditional welfare receipt be limited to two years. After this welfare recipients would be required to participate in community work schemes. Any who refused would forfeit their family's AFDC income. On the other hand, there was a guarantee that government would continue to act as an employer of last resort for those who were willing to play by the rules but unable to find work in the private sector. Furthermore, extra funds were to be provided for childcare and those welfare recipients who did move into work would 'buy back' some future welfare time.

Prior to the bill's publication there had been serious disagreements behind the scenes over how tough it should be (Weaver, 2000, pp. 232-5), but this in-house conflict became secondary once the bill was in the open. DLC supporters offered praise (The New Democrat, 1994), but many Democrats were wary. Many liberals just did not like the idea of time limits and were dismayed at the prospect of depriving the poorest families of benefit (Weaver, 1998, p. 383). And Republicans were in no mood to give Clinton credit. Newt Gingrich mocked: 'The President is brilliant at

\footnotetext{
${ }^{6}$ For qualified praise of the plan see the following newspaper editorials; 'A Good Place to Begin the Welfare Debate,' L.A. Times, June 19, 1994: M4; 'Clinton Takes on the Welfare Machine,' Chicago Tribune, June 16, 1994: 30; 'Message to Teen-Age Mothers,' New York Times, June 15, 1994: A24; 'A Solid Start on Welfare Reform,' Washington Post, June 16, 1994: A24.
} 
describing a Ferrari, but his staff continues to deliver a Yugo' (Marcus and Balz, 1994).

Whatever its merits, the WRA was overtaken by events when the GOP captured Congress in the 1994 mid-term elections after which the impetus was for more draconian change. In the summer of 1996, this left Clinton with a quandary when the Republican Congress presented him with their version of welfare reform. PRWORA replaced AFDC with a benefit named Temporary Assistance to Needy Families, available for a maximum of two years before recipients are required to engage in work related activity. Claimants can participate in government-sponsored activities such as subsidized employment for a further three years, but this marks the end of their assistance-as this five-year limit is a lifetime limit.

Clinton in fact twice blocked Republican welfare reform when it came accompanied by unpopular cuts that provided enough political cover for a veto (Weaver, 2000, p. 320). When the Republicans produced a stand-alone welfare bill, however, Clinton had to choose between competing voices in the White House. At a meeting of senior advisers, Secretary of Health and Human Services Donna Shalala, Chief-of-Staff Leon Panetta, and most policy advisers lined up against PRWORA. Lobbying in favour were the political advisers and one senior domestic policy adviser, Bruce Reed. Pollster Dick Morris was absent, but according to his account, Clinton, while deeply uneasy, heeded the political imperative; 'I told him flatly that a welfare veto would cost him the election' (1997, p. 300). Clinton's decision left those he had engaged specifically to design welfare reform furious (Ellwood, 1996; Bane, 1997). Presidential adviser George Stephanopoulos urged a veto, but notes his own 'complicity' in advocating the message to 'end welfare as we know it' throughout the 
1992 campaign 'even though ... it sent a message far more powerful than ... the fine print' of the actual proposals then being advanced (1999, p. 421).

In the end, the decision to sign PRWORA allowed Clinton to claim that he had fulfilled his 1992 campaign pledge, and with some political pay-off. Welfare is no longer such a festering potential wedge issue with the Democrats on the wrong side. After signing the legislation Clinton was eager to share credit for reform, particularly when it was widely perceived as a success. On the other hand, congressional Republicans, with greater legitimacy, also claimed credit for the reform and this episode, along with Nixon's experience with FAP, says much about the difficulty for pre-emptive leaders in leading from the front. Both Nixon and Clinton proposed quite complex and multi-faceted welfare plans, but the consequence for both was criticism from left and right—in turn suggesting the difficulty inherent in building a winning coalition in support of policy that steps outside the traditional ideological boundaries.

\section{Pre-Emptive Social Security Reform}

The logic of pre-emptive politics was also illustrated by Nixon's and Clinton's efforts at Social Security reform. Unlike AFDC, Old Age, Survivors, and Disability Insurance (OASDI), commonly know as Social Security, has grown into a large and popular program with an expansionary dynamic. Although confidence in this quasiuniversal, federal, earnings-related pension scheme has declined in recent years, Social Security remains the popular foundation of the U.S. pension system (Brain, 1992; Cook et al, 2002). In constant 1996 dollars, the average monthly Social Security payment in 1950 was $\$ 278$. By 1996 this had risen to $\$ 745$. In contrast, over the same period the average AFDC monthly payment went from $\$ 132$ to $\$ 134$ (Campbell, 2003, p. 16). Integrating the middle class, Social Security has gathered a large 'army 
of beneficiaries' that exacerbates the electoral risks traditionally associated with social programs that directly affect the middle class (Quadagno, 1991). Thus, just as the politics of welfare suggested that the crudest calculation would be to favour a harsher regime, so with Social Security the basic political imperative would be to extol the program and to see this as the path towards electoral dividends and legacy building. Again, however, just as the Democrats, prior to Clinton, were perceived as being on the wrong side of the welfare divide, so the Republicans were historically less trusted with Social Security (Shafer and Claggett, 1995). For Nixon this was especially problematic as Goldwater's ill-fated 1964 campaign had questioned the program's structure.

A more calculated GOP response had in fact already been seen in the 1950 s when Eisenhower explicitly supported Social Security while attempting to keep faith with his party's traditional fiscal conservatism by slowing its expansion. This approach failed when, despite Eisenhower's efforts, Congress added disability insurance to the program in 1956 (Berkowitz, 1987). Yet, Eisenhower's was a more appealing strategy for Nixon to follow than Goldwater's. Therefore, Nixon both attempted to demonstrate his support for enhancing Social Security and to limit the terms of this program's expansion. His aim was to reinforce his own political position by championing the idea of automatic indexation of Social Security benefits while undermining the political tool used by Congressional Democrats who preferred to enact $a d$ hoc benefit increases that came into effect near election time.

When Clinton came to office, Social Security remained highly popular in its own liberal political space as it had been even through the Reagan era. Indeed the program had become known as 'the third rail of American politics' ('touch it and die') with regard to reform efforts aimed at downsizing. This reference, however, does say 
something important about the significantly changed context in which elites discussed the future of the program. In the early 1970s, the assumption was that the program's benefits could be expanded and the political and policy quarrel was over how this would be done. Twenty years later, the prevailing mood was quite different with analysts talking of the need to rein in the program-even if it was not evident how politicians could do this and survive. Thus, just as with welfare, Nixon and Clinton were faced with policy contexts that did not sit comfortably with their party's traditional positioning; but in this case the sources of pressure were reversed. That is, on welfare, Nixon tried to accommodate his party to elite opinion, while on Social Security, the GOP needed to compromise with popular wishes. Clinton, on the other hand, moved his party to reconcile with popular opinion on welfare, but was being pushed by elites to contradict normal Democrat steadfast support for the existing Social Security framework.

Nixon's strategy was based on the idea that Social Security expansion could be limited through the development of 'automatic government' (Weaver, 1988). That is, the introduction of automatic indexation would make it more difficult for Democrats in Congress to justify enacting—and claiming credit for—inflationary $a d$ hoc benefit increases. Nixon's plans, however, were undermined by two main factors (Béland, forthcoming). First, changes in actuarial assumptions made bolder benefit increases possible in the short run. Social Security Commissioner Robert Ball presented new 'optimistic' assumptions that broke with the actuarial conservatism that had prevailed since the 1930s. Instead of assuming that wages would not grow in the future, policy-makers adopted a 'dynamic' actuarial model that made major benefit 
increases possible without significant tax hikes (Derthick, 1979, pp. 349-57). ${ }^{7}$ The triumph of actuarial optimism provided Congress with the opportunity to exhibit its apparent generosity towards the elderly. Second, powerful Democratic leaders in Congress, such as Wilbur Mills (D-Arkansas), opposed automatic indexation for the very reason that they preferred enacting ad hoc increases that they could use to claim credit with key electoral constituencies (Zelizer, 1998).

It is in this context that the debate concerning Social Security reform during Nixon's first mandate needs to be understood. In September 1969, Nixon called for a 10 percent benefit increase plus automatic indexation: 'I request that the Congress remedy the real losses to those who now receive Social Security benefits by increasing payments by 10 percent. Beyond that $\ldots$ The way to prevent future unfairness is to attach the benefit schedule to the cost of living' (Nixon, 1969). In December 1969, however, Mills' House Committee on Ways and Means reported its own Social Security bill early that called for a 15 percent benefit increase, but was silent on the matter of indexation. With a benefit increase far above inflation, this pleased traditional Democratic constituencies and was adopted as part of the Tax Reform Act (Social Security Administration, 1970).

By early 1971, however, Mills understood that he could no longer oppose the increasingly popular principle of automatic indexation, and so he allowed the measure to be integrated into a bill (HR1) which also contained Nixon's second, half-hearted, effort to reintroduce FAP's principles. Meanwhile, an amendment to the 1971 Debt Ceiling Extension Bill, a Vietnam war-related measure, provided a 10 percent increase in Social Security benefits retroactive to January 1st of that year. Since the

\footnotetext{
${ }^{7}$ Within the SSA, chief actuary Robert Myers opposed Ball's stance but finally lost the battle and left the federal government in 1970 (Berkowitz, 2003).
} 
1971 inflation rate was below 5 percent, this amendment further increased the program's average replacement rate, which increased from 36.3 percent in 1967 to 43 percent in 1971 (Myers, 1993).

The continuing controversy over the welfare reform proposals in HR1 meant that SFC did not reach agreement for over a year until June 1972. In the meantime, Mills pushed for a further, unprecedented, 20 percent increase in Social Security benefits (Hunter, 1972). The new 'dynamic' actuarial assumptions made this increase feasible without massive tax hikes, but Nixon opposed this measure. Instead, he suggested a 5 percent rise in benefits coherent with his containment strategy. On June 30, however, Congress adopted both automatic indexation and a 20 percent benefit increase and attached the measure to the 1972 Debt Ceiling Extension. Since the increase in benefits was now part of legislation necessary to the pursuit of the Vietnam War, Nixon had little choice but to agree. When signing the bill Nixon claimed credit for the enactment of automatic indexation, while barely acknowledging the 20 percent benefit increase (Nixon, 1972).

Overall, then, Nixon's pre-emptive containment strategy failed. In the end he did get automatic indexation but only after Congressional Democrats forced him into consenting to a series of large increases in benefit levels that created the inflationary momentum he had wanted to restrain. Moreover, his compromises did not redefine the politics of Social Security with Democrats still quick to proclaim themselves as the program's true champions. This underlying political partiality was illustrated by the tale of Social Security in the 1990s: ironically, however, the traditional partisan divide was reinforced despite Clinton's brief exploration of the possibility of exercising preemptive leadership by talking of program reform. 
Clinton's dilemma was that, while Social Security remained highly popular, an elite conventional wisdom had developed maintaining that demographic trends meant the program was not viable in the long-term in its existing format. Ever-present in the mass media and the discourse of many experts and politicians, demographic fears take the form of a conventional wisdom depicting a developing 'time bomb' as the elderly population grows in relation to the overall population (Béland and Waddan, 2000). Another idea that gained considerable ground in the later 1990s was that of partial privatisation of Social Security; and this push to redirect at least a proportion of payroll tax money to individual savings accounts was further stimulated by exceptional stock market performances. Advocates of privatisation remained aware of the political risks of taking on the 'army' of Social Security beneficiaries, but there was a growing movement to portray partial privatisation as not only feasible but unavoidable, even if the language was couched in terms of trying to 'save Social Security' (Béland, forthcoming).

During his second presidential mandate, Clinton made an increasing number of public references to Social Security reform (Cook et al, 2002, p. 241). In 1998, for example, Clinton used his State of the Union address to demand that Congress 'Save Social Security First' by employing the prospective federal surpluses to guarantee the long-term fiscal stability of Social Security instead of enacting massive tax cuts (Sloan, 1998). During the two years following the 1998 State of the Union address, Social Security reform proposals multiplied, and partial privatisation appeared as a significant item on the policy agenda. One example was the proposal presented in the spring of 1998 by Senators John Breaux (D-LA) and Judd Gregg (R-NH) 'that would have introduced a mandatory private tier using two percentage points of the existing payroll tax' (Derthick, 2001, p. 206). Breaux was an influential figure in the New Democrat circles, and the DLC had already stirred controversy within Democrat ranks by circulating policy documents suggesting partial privatisation style reforms, not only of Social Security but also of Medicare (Kendall, 1997; Shapiro, 1997). One 
problem in drafting a potential legislative compromise, however, was the political requirement to avoid any increase in the Social Security payroll tax. Such an increase had been an enduring political taboo since the Reagan era and had complicated efforts to devise a funding formula in the absence of a short-term 'fiscal crisis' (Weaver, 2003).

Eventually, after months of informal talks between key members of Congress and the administration, Clinton finally opposed partial privatisation in his 1999 State of the Union and recommended that savings accounts be created alongside the existing PAYGO-system. He also proposed to invest Social Security surpluses in equity (Clinton, 1999). These two measures represented an attempt to frame a political compromise that would win some Republican support without leading to Social Security privatisation. In this sense, the package was an attempted manifestation of pre-emptive leadership grounded in an acknowledgement of the financial logic that had been long promoted by conservatives. Unfortunately for Clinton, conservatives-including the influential Chairman of the Federal Reserve Bank, Alan Greenspan-strongly opposed the direct investment by the federal government of Social Security surpluses in equity. From their perspective, such investment model would have dangerously increased the economic power of the federal government in the U.S. (Glassman, 1998). Thus, there was no concrete legislative move towards Social Security privatisation during the Clinton presidency, and, in the end, there was more political mileage for Clinton in embracing traditional partisan postures and depicting himself as a zealous defender of the ever-popular Social Security against GOP attacks rather than engaging in a concerted effort to frame a legislative compromise.

\section{DISCUSSION}


Overall, then, Presidents Nixon and Clinton failed to develop a new ideological space for their welfare and Social Security proposals, and their inability to do so illustrates the complex and highly uncertain nature of pre-emptive leadership. In the field of Social Security reform, the legislative compromises imagined in the White House were never enacted. Nixon pushed for indexation rather than ad hoc benefit increases in an effort to deprive Democrat lawmakers of a favourite electoral tool, but ended up with indexation after a series of large benefit boosts. The end result was to increase rather than control the fiscal pressures within the program with little evidence of political benefit accruing to the GOP. The Clinton administration, inheriting the long-term outcome of those fiscal pressures, attempted to reach a compromise with moderate Republicans about Social Security privatisation. The President, however, finally settled on a traditional Democratic stance, which was politically profitable (and may indeed be good policy), but which left those pointing to the projected fiscal shortcomings of the program frustrated. In the field of social assistance, Nixon advanced a significant change having 'eyed a chance to steal the Democrats' thunder' (Greenberg, 2003, p. 310), but was assailed by all sides when he did so leading him effectively to give up on welfare reform as his party returned to its more established comfort zone of bashing welfare dependence. Clinton, too, presented a bill that would have changed the nature of welfare, but the 1994 congressional elections changed the balance of power and his original proposals were left in the dust as he signed on to a distinctly more conservative reform causing one of the biggest internal rifts within the administration.

These legislative outcomes, either nothing or too much, indicate the difficulties Nixon and Clinton experienced in coming to terms with their pre-emptive context when attempting to fashion substantive policy legacies compatible with 
inescapable political imperatives. One problem lies with the complexity of devising what might best be described as a two-step approach to policy development combining elements of conservative and liberal philosophies. Such efforts are likely to result in complex and ambivalent legislation that will be vulnerable to ideological attack from the left and right. ${ }^{8}$ The U.S. political system is one in which it is possible to build winning legislative coalitions across party lines-as Nixon did on Revenue Sharing and Clinton did on NAFTA and trade relations with China-but this is a tortuous path and congressional opponents will not want to hand too many victories to a president of a different party. In a way, it is easier for pre-emptive presidents such as Nixon and Clinton to manipulate political discourse to secure election, and even reelection, than to have Congress enact complex and sometimes ideologically ambiguous legislative compromises that would constitute enduring policy legacies. This is not to deny the significance of the Social Security amendments of the early 1970s and PRWORA as they were manifestly landmark pieces of social policy legislation. To claim, however, that these measures represented policy and political successes for Nixon and Clinton is disingenuous. It might have made immediate political sense for the two Presidents to sign the respective bills when presented with them by Congress, but there was a qualitative ideological difference in the legislation they signed from that they had originally aspired to. In turn, this meant that these legislative 'accomplishments' could not be used as a model for either further policy reform or effective long-term restructuring of political coalitions.

\footnotetext{
${ }^{8}$ Although it falls outside the scope of this study, one should note that Clinton's Health Security plan also represented a complex and ambivalent attempt to frame a legislative compromise (Skocpol, 1996; Hacker, 1997).
} 
The examples of Nixon and Clinton also suggest that pre-emption works at different levels. Whatever the merits of the former's attitude towards Social Security and the latter's attitude towards welfare, they were clearly motivated, to some extent, by concerns that they were as being in tune with popular sentiment. The motives of Nixon with regard to welfare reform and Clinton vis-à-vis Social Security reform are in some ways more intriguing, because on these issues they upset many in their own ranks for no obvious short-term electoral purpose. Here they seem to have been guided, at least briefly, more by the dominant elite perspective rather than by public opinion. If they had pushed ahead with reform in these areas then they might have upset the established political applecart, but trying to negotiate intricate proposals in the pre-emptive context, when partisanship is high, proved too difficult a task.

As it is, Nixon and Clinton are remembered for scandals as much as legislative achievements, and this feature is certainly related to the nature of pre-emptive leadership. In such a context, this article provides more historical ground to Skowronek's typology of presidential leadership. More specifically, it contributes to our understanding of pre-emptive policy efforts, and of how a pre-emptive political environment can affect both electoral strategies and legislative outcomes. 


\section{LIST OF REFERENCES}

Anderson, M. (1988) Revolution. New York: Harcourt Brace Jovanovich.

Arnold, P. (1995) 'Determinism and Contingency in Skowronek's Political Time' in Polity, XXVII (3), 497-505.

Baer, K. (2000) Reinventing Democrats: the Politics of Liberalism from Reagan to Clinton. Lawrence: University Press of Kansas.

Bane, M.J. (1997) 'Welfare as We Might Know It', The American Prospect, $\mathrm{n}^{\circ}$ 30, 47-55.

Béland, D. (forthcoming) Social Security: History and Politics from the New Deal to the Privatization Debate. Lawrence: University Press of Kansas.

Béland, D. and Waddan, A. (2000) 'From Thatcher (and Pinochet) to Clinton? Conservative Think Tanks, Foreign Models and US pensions reform,' Political Quarterly 71, 202-210.

Béland, D., Vergniolle de Chantal, F. and Waddan, A. (2002) 'Third Way Social Policy: Clinton's Legacy?', Policy and Politics, 30 (1), 19-30.

Berman, W. (1994) America's Right Turn: From Nixon to Bush. Baltimore: John Hopkins University Press.

Berkowitz, E. (1987) Disabled Policy: America's Programs for the Handicapped. New York: Cambridge University Press.

Berkowitz, E. (2003) Robert Ball and the Politics of Social Security. Madison: University of Wisconsin Press.

Bowler, M. (1974) The Nixon Guaranteed Income Proposal: Substance and Process in Policy Change. Cambridge, Massachusetts: Bollinger.

Burke, V. and Burke, V. (1974) Nixon's Good Deed: Welfare Reform. New York: Columbia University Press.

Brain, C. (1991) Social Security at the Crossroads: Public Opinion and Public Policy. New York: Garland Publishing.

Campbell, A. L. (2003) How Policies Make Citizens: Senior Political Activism and the American Welfare State. Princeton: Princeton University Press.

Clinton, W.J. (1992) 'Nominee Clinton Describes Vision of New Covenant', Congressional Quarterly Weekly Report, 18 July, 2128-2130.

Clinton, W.J. (1999) President William Jefferson Clinton State of the Union Address. Washington DC: The White House, Office of the Press Secretary, 19 January. 
Cook, F.L., Barabas, J. and Page, B. (2002) 'Invoking Public Opinion: Policy Elites and Social Security,' Public Opinion Quarterly 66, 235-264.

Derthick, M. (2001) 'The Evolving Old Politics of Social Security,' in M. Levin, M. Landy and M. Shapiro (eds), Seeking the Center: Politics and Policymaking at the New Century. Washington DC: Georgetown University Press, pp. 193-214.

Derthick, M. (1979) Policymaking for Social Security. Washington DC: Brookings Institution.

Ellwood, D. (1996) 'Welfare Reform As I Knew It', The American Prospect, n²6, 22-29.

Erskine, H., (1975) 'The Polls: Government Role in Welfare', Public Opinion Quarterly, XXXIX (2), 257-74.

Galston, W. and Kamarck, E. (1989) The Politics of Evasion: Democrats and the Presidency. Washington DC: Progressive Policy Institute.

Gilens, M. (1996) 'Race Coding and White Opposition to Welfare', American Political Science Review, 90 (3), 593-604.

Glassman, J. (1998) 'Uncle Sam on Wall Street? No,' Washington Post December 8, A21.

Greenberg, D. (2003) Nixon's Shadow: The History of an Image, New York, W.W. Norton.

Hale, J. (1995) 'The Making of the New Democrats' in Political Science Quarterly, 110 (2), 207-32.

Hunter, M. (1972) 'Mills Asks 20\% Rise in Social Security Aid,' New York Times, 24 February, 19.

Kendall, D. (1997) 'Modernizing Medicare and Medicaid: The First Step Toward Universal Health Care', in W. Marshall ed., Building the Bridge: 10 Big Ideas to Transform America. Washington DC: Progressive Policy Institute, pp. 57-74.

Kotlowski, D. (2001) Nixon's Civil Rights: Politics, Principle and Policy. Cambridge, Massachusetts: Harvard University Press.

Marcus, R. and Balz, D. (1994) 'Clinton Outlines Plan to Break Welfare Cycle', The Washington Post, 15 June, A1 and A18.

Marshall W. and Schram M. (eds) (1993) Mandate For Change. New York: Berkley Books/the Progressive Policy Institute.

Mayhew, D. (1991) Divided We Govern: Party Control and Lawmaking, and Investigations 1946-1990. New Haven: Yale University Press. 
Mead, L. (1986) Beyond Entitlement: the Social Obligations of Citizenship. New York: Free Press.

Mead, L. (1992) The New Politics of Poverty: the Nonworking Poor in America. New York: Basic Books.

Milkis, S.M. (1995) 'What Politics Do Presidents Make', Polity, XXVII (3), 485-96.

Morris, D., (1997) Behind the Oval Office: Winning the Presidency in the Nineties. New York: Random House.

Moynihan, D.P. (1973) The Politics of a Guaranteed Income: Community Action in the War on Poverty. New York: Random House.

Murray, C. (1984) Losing Ground: American Social Policy, 1950-1980. New York: Basic Books.

Myers, R. (1993) Social Security (fourth edition). Philadelphia: Pension Research Council/University of Pennsylvania Press.

The New Democrat (1994) 'Status Quo Plus: Some Would Save Welfare as We Know It', The New Democrat, August-September, 6.

New York Times (1969) 'Welfare Reform', New York Times, 15 August, 46.

Nixon, R. (1978) The Memoirs of Richard Nixon. New York: Grosset and Dunlap.

Nixon, R. (1972) 'Statement on Signing a Bill Extending Temporary Ceiling on National Debt and Increasing Social Security Benefits' (July $1^{\text {st }}, 1972$ ) in Public Papers of the Presidents of the United States, Richard Nixon, 1972. Washington DC: United States Government Printing Office, pp. 723-724.

Nixon, R. (1971) 'Special Message to the Congress on Social Security' (September 25, 1969), Public Papers of the Presidents of the United States, Nixon, 1969, Washington DC: United States Government Printing Office, 1971, pp. 740-745.

Phillips, K. (1969) The Emerging Republican Majority. New York: Doubleday.

Quadagno, J. (1994) The Color of Welfare: How Racism Undermined the War on Poverty. New York: Oxford University Press.

Quadagno, J. (1991) 'Interest Group Politics and the Future of U.S. Social Security' in J. Myles and J. Quadagno (eds), States, Labor Markets, and the Future of Old-Age Policy. Philadelphia: Temple University Press, pp. 36-59.

Shafer, B. and Claggett, W. (1995) The Two Majorities: the Issue Context of Modern American Politics. Baltimore: John Hopkins University Press. 
Shapiro, R. (1997) 'A New Deal on Social Security', in W. Marshall ed., Building the Bridge: 10 Big Ideas to Transform America. Lanham, Maryland: Rowman and Littlefield/Progressive Policy Institute, pp. 39-57.

Skowronek, S. (1993) The Politics Presidents Make: Leadership From John Adams to Bill Clinton. Cambridge, Massachusetts: Harvard University Press.

Skowronek, S. (1995) 'Response', Polity, XXVII (3), 517-34.

Skowronek, S. (1997) The Politics Presidents Make: Leadership From John Adams to Bill Clinton (second edition). Cambridge, Massachusetts: Harvard University Press.

Sloan, A. (1998) 'The Surplus Shell Game: How Beltway Budgeters Manipulate the Bottom Line', Newsweek, 19 January, 28.

Somers, M. \& F. Block (forthcoming) 'From Poverty to Perversity: Ideational Embeddedness and the Rise and Reprise of Market Liberalism', American Sociological Review.

Small, M. (1999) The Presidency of Richard Nixon, Lawrence: University Press of Kansas.

Social Security Administration, (1970) 'Social Security Benefits Increased,' Social Security Bulletin, 33 (2), February, 1.

Stephanopolous, G. (1999) All Too Human: A Political Education, Boston: Little Brown and Company.

Teles, S. (1996) Whose Welfare: AFDC and Elite Politics, University Press of Kansas.

Tobin, J. (1968) 'Raising the Incomes of the Poor', in K. Gordon (ed), Agenda for the Nation: papers on domestic and foreign policy issues, Washington DC: Brookings Institution Press.

U.S. (1968) National Advisory Commission on Civil Disorders, Report of the National Commission on Civil Disorders, New York: Bantam Books.

U.S. (1969) President's Commission on Income Maintenance Programs, Report of the President's Commission on Income Maintenance Programs: Poverty Amid Plenty, Washington DC: United States Government Printing Office.

U.S. (1971) Statistical Abstract of the United States: 1971. Washington DC: Bureau of the Census).

U.S. (1998a) Committee on Ways and Means, U.S. House of Representatives, 1998 Green Book: Background Material and Data on Programs within the Jurisdiction of the Committee on Ways and Means. Washington DC: United States Government Printing Office. 
U.S. (1998b) Statistical Abstract of the United States: 1998. Washington DC: Bureau of the Census.

Weaver, R.K. (2003) Public Pension Reform in the United States. Paper presented at the workshop Social Policy Responses to Population Ageing in the Globalization Era (Hokkaido University, March).

Weaver, R.K. (2000) Ending Welfare As We Know It. Washington DC: Brookings Institution Press.

Weaver, R.K. (1998) 'Ending Welfare As We Know It', in M. Weir ed., The Social Divide: Political Parties and the Future of Activist Government. Washington DC: Brookings Institution Press, pp. 361-416.

Weaver, R.K. (1988) Automatic Government: The Politics of Indexation. Washington DC: Brookings Institution.

Weaver, R.K., Shapiro, R. and Jacobs, L. (1995) 'The Polls-Trends: Welfare', Public Opinion Quarterly, n 59, 606-627.

Zelizer, J. (1998) Taxing America: Wilbur D. Mills, Congress, and the State, 19451975, New York, Cambridge University Press. 